\title{
Economic Feasibility Analysis of Onion Cultivation under Mulching and Fertigation in Vertisol in Semi-arid Indian Condition
}

\author{
P. R. Anjitha Krishna ${ }^{1 *}$, B. Maheshwara Babu ${ }^{1}$, A. T. Dandekar ${ }^{2}$, R. H. Rajkumar ${ }^{1}$, \\ G. Ramesh ${ }^{1}$ and S. R. Balanagoudar ${ }^{1}$
}

${ }^{1}$ Department of Soil and Water Engineering, College of Agricultural Engineering, University of Agricultural Sciences, Raichur, India

${ }^{2}$ College of Agriculture, VC Farm, Mandya, University of Agricultural Sciences, Bangalore, India

*Corresponding author

\section{A B S T R A C T}

\begin{tabular}{|l|}
\hline K e y w or d s \\
Mulch, Fertigation, \\
$\begin{array}{l}\text { Net present worth, } \\
\text { Payback period, } \\
\text { Onion }\end{array}$ \\
\hline Article Info \\
\hline $\begin{array}{l}\text { Accepted: } \\
\text { 14 January } 2021 \\
\text { Available Online: } \\
\text { 10 February } 2021\end{array}$ \\
\hline
\end{tabular}

\section{Introduction}

Drip irrigation, an effective means for water conservation ensures uniformity in distribution of water and is often used with mulch (organic or inorganic). China, Japan, and South Korea are the greatest users of plastic mulches, constituting about $80 \%$ of the global usage (Kader et al., 2019). Mulching reduces evaporation and maintains optimum soil moisture in the soil; thereby control the root zone thermal environment. The influence
Onion crop is highly prone to yield loss from water stress and weed invasion. Mulching could be a better management practice for onion farmers in India for improving the productivity. The field experiment in the study included onion cultivation in raised beds in Vertisol under three levels of mulching (white plastic mulch, paddy straw mulch and control) and three levels of fertilizer rates (50, 75 and $100 \%$ of recommended dose of fertilizers $\left(125,50\right.$ and $125 \mathrm{~kg} \mathrm{ha}^{-1}$ of nitrogen, phosphorus and potassium). The plastic mulch with fertigation of $100 \%$ RDF was recorded with highest net present worth (Rs. 712578), benefit cost ratio (1.49), internal rate of return (522\%) and lowest payback period (0.66). The drip fertigation with plastic mulch was found to be an economically viable option to be recommended among farmers in arid and semi arid climate.

of mulching on yield, soil water content, soil temperature, soil nutrients and soil microbes have been accounted in experiments conducted in different parts of the world (Ma et al., 2018). Drip and mulching together improve the water use efficiency and crop productivity, due to reduction in soil evaporation, increased transpiration, increased soil water storage, increased soil temperature and increased activity of soil nutrients (Jiang et al., 2018). Mulches can decrease the crop water requirement by $10-20 \%$, as it acts as a 
moisture barrier that diminishes soil evaporation. Apart from this, plastic mulch modifies the radiation budget (absorptivity vs. reflectivity) at the soil-atmosphere interface and positively influences the microclimate in the crop root zone (Filipovic et al., 2016). Both organic and inorganic mulch materials are effective in controlling soil evaporation especially in high frequency irrigation systems, where the soil surface gets wet frequently (Zribi et al., 2015). The surface cover protects the top soil from mechanical perturbations due to tillage, rainfall or crust formation as well. This mechanical protection of top soil, enhanced root development, mucilage production and soil fauna activities promote the soil aggregate stability (Steinmetz et al., 2016; Wang et al., 2017). Different organic and inorganic mulches can also suppress pest attack in onion (Quintanilla-Tornel et al., 2016) and salt accumulation in the surface soil layers (Tan et al., 2017 and Li et al., 2018). The use of paddy straw as mulching material is one of the promising alternatives for straw management and has immense economic value under Indian condition (Roy and Kaur, 2015).

Onion is one of the most important export oriented crop, which is highly susceptible to yield drop due to high rainfall, disease attack, weed competition and poor management scenarios. The shallow root system of onion is highly sensitive to the soil water and nutrient availability in the crop root zone, which make it less competitive to weeds. The bulb yield can be reduced to the extent of 48 to $80 \%$ depending upon the duration, intensity of weed growth and weed competition (Patel et al., 1983). Water stress during crop growth results in decreased bulb size and decaying of bulbs during storage (Ortola and Knox, 2015). Mulching as integral component of intensive vegetable production system was found to increase the earliness, yield and quality of onion (Anisuzzaman et al., 2009; Lalitha et al., 2010; Ujjainiya and Choudhary, 2019). Drip fertigation with mulching is a proper management option for shallow crops in arid and semi arid regions, which ensure the water and nutrient availability right within the crop root zone. The present study was carried out to analyze the cost economics of onion (Arka Niketan variety) cultivation with mulching (plastic mulch, paddy straw mulch and control) and fertigation (50, 75 and $100 \%$ of recommended dose of fertilizers (RDF)) in Vertisol in North Eastern Dry Zone of Karnataka.

\section{Materials and Methods}

Field trials were conducted in rabi season in 2018-19 and 2019-20 at the Experimental Research Plot, College of Agricultural Engineering, University of Agricultural Sciences, Raichur, Karnataka, India in split plot design with three levels of main treatments (white plastic mulch, paddy straw mulch and control) and three levels of subtreatments (fertigation at 50, 75 and 100\% $\mathrm{RDF})$, replicated thrice. The RDF included application of 125,50 and $125 \mathrm{~kg} \mathrm{ha}^{-1}$ of nitrogen, phosphorus and potassium. Sulfur was applied at the rate of $50 \mathrm{~kg} \mathrm{ha}^{-1}$ in all the sub-treatment levels. The onion seedlings were transplanted at $15 \mathrm{~cm} \times 10 \mathrm{~cm}$ spacing in the first week of November to raised beds of $13.0 \mathrm{~m} \times 0.9 \mathrm{~m}$. Drip laterals were installed at $45 \mathrm{~cm}$ spacing. After the installation of drip laterals, the beds were covered with 25 micron white plastic mulch sheets. The paddy straw was spread on the raised beds to a thickness of $2.5 \mathrm{~cm}$. About $5.0 \mathrm{~kg}$ of paddy straw was used in each bed (Ram et al., 2013; Lakew et al., 2014; Peng et al., 2015 and Singha et al., 2018). The total duration of the crop was 145-160 days. Apart from the main and sub treatments, a residual control was also accommodated in the field, which received no external nutrient applications (i.e. 
farm yard manure and fertigation), but drip irrigation was given according to the schedule. The treatments were received $100 \%$ of crop evapotranspiration at two days interval (except on Sundays) through drip system consisting of two laterals at $45 \mathrm{~cm}$ spacing on the raised beds. The emitters were at a spacing of $20 \mathrm{~cm}$ and the duration of irrigation varied among different crop growth stages.

The cost incurred in cultivation was worked out for different treatments, which included the cost of installation of drip fertigation system with and without mulches and cost of field operations. Net return, benefit-cost ratio (BC ratio), payback period and internal rate of return (IRR) were calculated separately for each treatment on per hectare basis. The layout of the drip system and its requirement depends on size, shape, and topography of the field. The initial cost involved is the major limiting factor towards adoption of drip system. The following assumptions were made for the economic analysis:

The life period of PVC pipe lines were considered as 10 years

Annual interest rate as $12 \%$

Salvage value of the drip system was considered as $10 \%$ of the initial cost

Area of cultivation was assumed to be 1 ha $(100 \mathrm{~m} \times 100 \mathrm{~m})$ with a bore well at one corner of the field

Crop was assumed to be cultivated in one season (rabi) per year

The procedure followed for the cost economic analysis of the experiment treatments is briefly described here.

\section{Calculation of fixed cost}

Fixed cost consists of initial investment, interest rate at $12 \%$ per annum on the capital, and depreciation on the system at the rate of
$10 \%$ per annum on the capital at the initial period. The cost of drip irrigation system was included under fixed cost. The depreciation was calculated using eq. (1).

$\mathrm{D}=\frac{\mathrm{C}-\mathrm{S}}{\mathrm{L}}$

Where, $\mathrm{D}=$ Depreciation;

$\mathrm{C}=$ Capital cost;

$\mathrm{S}=$ Salvage value; and

$\mathrm{L}=$ Useful life, years.

The interest over the investment is calculated as follows (Eq. (2)):

$\mathrm{I}=\frac{\mathrm{c}+\mathrm{s}}{2} \times \mathrm{i}$

Where, $\mathrm{i}=$ Interest rate, $\%$.

\section{Calculation of operating cost}

It includes expenses for various plant protection activities carried out during the crop season. It involves charges on drip installation, mulching, land preparation, seeds, irrigation, transplanting, weeding, farm yard manure (FYM), fertilizers and chemicals (weedicides, pesticides, insecticides etc.), harvesting and electricity. The energy consumption was calculated from total operating hours of drip system.

\section{Calculation of gross income and benefit cost ratio}

The gross income from the crop was calculated from yield and prevailing market price of onion. Benefit-cost ratio (BCR) indicates the return from the crop under each treatment. It can be calculated by eq. (3) (Reddy and Ram, 2011). If the BCR obtained is more than one, the project is considered acceptable. 
$\mathrm{BCR}=\frac{\sum_{\mathrm{t}=1}^{\mathrm{n}} \mathrm{B}_{\mathrm{t}}(1+\mathrm{i})^{-1}}{\sum_{\mathrm{t}=1}^{\mathrm{n}} \mathrm{C}(1+\mathrm{i})^{-1}}$

Eq. (3)

Where, $\mathrm{Bt}=$ Benefit in $\mathrm{i}^{\text {th }}$ year;

$\mathrm{Ct}=$ Cost in $\mathrm{i}^{\text {th }}$ year;

$\mathrm{I}=$ Discount rate.

$\mathrm{t}=$ Number of years.

The assumptions taken for the calculation of $\mathrm{BCR}$ are listed below.

Total area of crop production is 1 ha

The topography of the land is flat

The water source is present at the corner of the field

The market price of onion as Rs.10 per $\mathrm{kg}$

\section{Calculation of payback period}

The time required to obtain the invested amount is represented by payback period, which is expressed by eq. (4). The shorter the payback period, better the project would be.

Payback period (years) $=\frac{\text { Initial investment }}{\text { Constant anmual cash inflow }}$

Eq. (4)

\section{Internal rate of return (IRR)}

It is the discount rate at which the net present worth (NPW) of a project becomes zero. NPW is the difference between present value of cash inflows and present value of cash outflows over a period of time. The formula for calculation of IRR is given in eq. (5).

$0=\mathrm{NPW}=\sum_{\mathrm{t}=1}^{\mathrm{t}} \frac{\mathrm{C}_{\mathrm{t}}^{\mathrm{a}}}{(1+1 \mathrm{RR})^{\mathrm{t}}}-\mathrm{C}_{0}$

Where, $\mathrm{C}_{\mathrm{t}}=$ Net cash inflow during the period $\mathrm{t}$;

$\mathrm{C}_{0}=$ Total initial investment cost; $\mathrm{t}=$ Number of time periods.

The IRR was calculated though trial and error method.

\section{Results and Discussion}

The total cost of cultivation incurred under different mulches and fertigation levels were calculated (sample calculation in Table 1). The total cost incurred for the installation of the drip fertigation system was Rs. 1,46,746 $\mathrm{ha}^{-1}$. The plastic mulch treatments had the highest total cost of cultivation (i.e. Rs. 2,52,639 ha- $\mathrm{hs}^{-1}$. 2,49,711 ha $\mathrm{ha}^{-1}$ and Rs. $2,46,608 \mathrm{ha}^{-1}$, under application of 100,75 and $50 \%$ RDF fertigation, respectively). The total cost of cultivation under straw mulch treatments with fertigation of 50, 75 and $100 \%$ RDF was Rs. 2,21,203, Rs. 2,24,306 and Rs. 2,27,234, respectively. The total cost of cultivation for the plastic mulched and paddy straw mulched treatments were 19.9 to $20.5 \%$ and 7.9 to $8.1 \%$ higher than the control treatments at different levels of fertigation, respectively. The higher initial investment is one of the limiting factors towards adoption of drip system with mulching. The economic feasibility of different treatments is described below in terms of net present worth (NPW), benefit cost ratio, payback period and internal rate of return (IRR) (sample calculation Table 2\&3). To workout these economic parameters the average cost of cultivation and yield data of 2018-19 and 2019-20 were taken into consideration.

\section{Net present worth}

The highest net present worth (NPW) of Rs. $7,12,578$ was observed under the plastic mulch treatment with fertigation of $100 \%$ RDF $\left(\mathrm{M}_{2} \mathrm{~F}_{3}\right)$, followed by plastic mulch treatment with fertigation of $75 \%$ RDF $\left(\mathrm{M}_{2} \mathrm{~F}_{2}\right)$, i.e. Rs.4,75,677. The control treatment with fertigation of $50 \%$ RDF $\left(\mathrm{M}_{3} \mathrm{~F}_{1}\right)$ and the residual control treatment without mulching and fertigation were uneconomical. The net present worth from plastic mulched treatments were 400 to $800 \%$ 
higher than the control treatments, whereas the paddy straw mulched treatments resulted in net present worth, 130 to $196 \%$ higher than the control treatments (Table 4).

The increment in net present worth from plastic mulched and paddy straw mulched treatments were as a result of higher yield obtained, as net present worth is proportional to gross return. Comparable results were also found in studies conducted by Reddy et al (2012) and Rao et al (2019).

\section{Benefit cost ratio}

Benefit cost ratio ( $\mathrm{BC}$ ratio) was calculated as a ratio of gross return from the project to the cost involved in implementation of the project. $\mathrm{BC}$ ratio of more than one is desirable for its recommendation. The highest benefit cost ratio of 1.49 was reported from the plastic mulch treatment with fertigation of
$100 \% \operatorname{RDF}\left(\mathrm{M}_{2} \mathrm{~F}_{3}\right)$. This was followed by plastic mulch treatment with fertigation of $75 \% \operatorname{RDF}\left(\mathrm{M}_{2} \mathrm{~F}_{2}\right)$ and plastic mulch treatment with fertigation of $50 \% \operatorname{RDF}\left(\mathrm{M}_{1} \mathrm{~F}_{1}\right)$, with $\mathrm{BC}$ ratio's of 1.33 and 1.25 , respectively. The $\mathrm{BC}$ ratios recorded under paddy straw mulched treatments were higher than $\mathrm{BC}$ ratios obtained under control treatments, i.e. 1.25, 1.12 and 1.02 for $\mathrm{M}_{1} \mathrm{~F}_{3}$ (fertigation of $100 \%$ RDF), $\mathrm{M}_{1} \mathrm{~F}_{2}$ (fertigation of $75 \% \mathrm{RDF}$ ) and $\mathrm{M}_{1} \mathrm{~F}_{1}$ (fertigation of $50 \% \mathrm{RDF}$ ), respectively. This was also reported by Inusah et al., (2013). The control treatment with fertigation of $50 \% \mathrm{RDF}$ and the residual control treatment (RC) were uneconomical (as BC ratio < 1) (Table 4). The values are less than reported values from Reddy et al (2012) and Chauhan et al., (2017) as only one cropping season per year was assumed in the present study and the initial cost accounted was more due to detailed estimate.

Table.1 Calculation of total cost of cultivation under drip fertigation system with white plastic mulch and $100 \%$ of $\mathrm{RDF}\left(\mathrm{M}_{2} \mathrm{~F}_{3}\right)$

\begin{tabular}{|c|c|c|c|}
\hline \multirow[t]{2}{*}{ Sl. No. } & \multirow[t]{2}{*}{ Particulars } & \multicolumn{2}{|c|}{ Cost $\left(\right.$ Rs. ha $\left.{ }^{-1}\right)$} \\
\hline & & $\begin{array}{l}\text { Season-I } \\
(2018-19)\end{array}$ & $\begin{array}{l}\text { Season-II } \\
(2019-20)\end{array}$ \\
\hline 1 & Ploughing & 1200 & 1200 \\
\hline 2 & Rotavator & 2750 & 2750 \\
\hline 3 & Bed Preparation & 1400 & 1400 \\
\hline 4 & Transplanting & 7000 & 7000 \\
\hline 5 & Plastic mulch & 39000 & 39000 \\
\hline 6 & Fixing the plastic sheet and hole making & 1750 & 1750 \\
\hline 7 & Plant protection, spraying, fertilizer application & 4500 & 4500 \\
\hline 8 & Harvesting & 4200 & 4200 \\
\hline 9 & Seed & 15000 & 15000 \\
\hline 10 & FYM & 1600 & 1600 \\
\hline 11 & Fertilizers & 12800 & 12800 \\
\hline 12 & Electricity cost & 500 & 500 \\
\hline \multirow[t]{6}{*}{13} & Post harvest management practices & 1400 & 1400 \\
\hline & Variable cost & 93100 & 93100 \\
\hline & Interest on variable cost (@ 3\%) & 2793 & 2793 \\
\hline & Fixed cost & 146746 & 146746 \\
\hline & Land rent @ 10,000 ha ${ }^{-1}$ & 10000 & 10000 \\
\hline & Total cost of cultivation & 252639 & 252639 \\
\hline
\end{tabular}


Table.2\&3 Economic feasibility analysis-sample calculation for treatment $\mathrm{M}_{2} \mathrm{~F}_{3}$

\begin{tabular}{|c|c|c|c|c|c|}
\hline \multicolumn{7}{|c|}{ Plastic mulch with fertigation of 100 \% $\mathbf{R D F}\left(\mathbf{M}_{\mathbf{2}} \mathbf{F}_{\mathbf{3}}\right)$} \\
\hline $\begin{array}{c}\text { Yea } \\
\mathbf{r}\end{array}$ & $\begin{array}{c}\text { Cost of } \\
\text { cultivation }\end{array}$ & $\begin{array}{c}\text { Gross } \\
\text { return }\end{array}$ & $\begin{array}{c}\text { Discounted factor, } \\
\mathbf{1 2 \%}\end{array}$ & $\begin{array}{c}\text { Discounted } \\
\text { cost }\end{array}$ & $\begin{array}{c}\text { Discounted } \\
\text { benefit }\end{array}$ \\
\hline $\mathbf{0}$ & 25000 & 0 & 1.0000 & 25000 & 0 \\
\hline $\mathbf{1}$ & 252639 & 383179 & 0.89286 & 225571 & 342124 \\
\hline $\mathbf{2}$ & 252639 & 383179 & 0.79719 & 201403 & 305468 \\
\hline $\mathbf{3}$ & 252639 & 383179 & 0.71178 & 179824 & 272739 \\
\hline $\mathbf{4}$ & 252639 & 383179 & 0.63552 & 160557 & 243517 \\
\hline $\mathbf{5}$ & 252639 & 383179 & 0.56743 & 143354 & 217426 \\
\hline $\mathbf{6}$ & 252639 & 383179 & 0.50663 & 127995 & 194130 \\
\hline $\mathbf{7}$ & 252639 & 383179 & 0.45235 & 114281 & 173331 \\
\hline $\mathbf{8}$ & 252639 & 383179 & 0.40388 & 102037 & 154760 \\
\hline $\mathbf{9}$ & 252639 & 383179 & 0.36061 & 91104.3 & 138178 \\
\hline $\mathbf{1 0}$ & 252639 & 383179 & 0.32197 & 81343.1 & 123373 \\
\hline & & & Total & 1452469 & 2165046 \\
\hline & & & BC ratio & 1.49 & \\
\hline & & & NPW & 712578 & \\
\hline & & IRR & $522.16 \%$ & \\
\hline & & Payback period & 0.66 & \\
\hline
\end{tabular}

\begin{tabular}{|c|c|c|c|c|c|}
\hline \multicolumn{6}{|c|}{$\mathbf{M}_{2} \mathbf{F}_{3}$} \\
\hline Year & $\begin{array}{c}\text { Cost of } \\
\text { cultivation }\end{array}$ & $\begin{array}{l}\text { Gross } \\
\text { return }\end{array}$ & $\begin{array}{c}\text { Discounted factor, } \\
522.16 \%\end{array}$ & $\begin{array}{l}\text { Discounted } \\
\text { cost }\end{array}$ & $\begin{array}{c}\text { Discounted } \\
\text { benefit }\end{array}$ \\
\hline $\mathbf{0}$ & 25000 & 0 & 1.0000 & 25000 & 0 \\
\hline 1 & 252639 & 383179 & 0.1607 & 40607 & 61589 \\
\hline 2 & 252639 & 383179 & 0.0258 & 6527 & 9899 \\
\hline 3 & 252639 & 383179 & 0.0042 & 1049 & 1591 \\
\hline 4 & 252639 & 383179 & 0.0007 & 169 & 256 \\
\hline 5 & 252639 & 383179 & 0.0001 & 27 & 41 \\
\hline 6 & 252639 & 383179 & 0.0000 & 4 & 7 \\
\hline 7 & 252639 & 383179 & 0.0000 & 1 & 1 \\
\hline 8 & 252639 & 383179 & 0.0000 & 0 & 0 \\
\hline 9 & 252639 & 383179 & 0.0000 & 0 & 0 \\
\hline \multirow[t]{6}{*}{10} & 252639 & 383179 & 0.0000 & 0 & 0 \\
\hline & & & Total & 73384 & 73384 \\
\hline & & & $\mathrm{BC}$ ratio & 1.00 & \\
\hline & & & NPW & -0.005 & \\
\hline & & & IRR & $522.16 \%$ & \\
\hline & & & Payback period & 0.66 & \\
\hline
\end{tabular}


Table.4 Economic feasibility of cultivation of onion under different mulches and fertigations levels

\begin{tabular}{|c|c|c|c|c|c|c|c|}
\hline Treatment & Yield (t ha $\left.{ }^{-1}\right)$ & $\begin{array}{l}\text { Total cost } \\
\text { of } \\
\text { cultivation } \\
\left(\text { Rs. } \text { ha }^{-1}\right)\end{array}$ & $\begin{array}{c}\text { Gross } \\
\text { return }(\text { Rs. } \\
\left.\text { ha }^{-1}\right)\end{array}$ & $\begin{array}{c}\text { Net present } \\
\text { worth (Rs. ha } \\
\left.\mathbf{1}^{-}\right)\end{array}$ & $\begin{array}{c}\mathrm{BC} \\
\text { ratio }\end{array}$ & $\begin{array}{c}\text { IRR } \\
(\%)\end{array}$ & $\begin{array}{c}\text { Payback } \\
\text { period } \\
\text { (years) }\end{array}$ \\
\hline $\mathbf{M}_{1} \mathbf{F}_{1}$ & 23.04 & $2,21,203$ & $2,30,449$ & 27,242 & 1.02 & 35.17 & 0.96 \\
\hline $\mathbf{M}_{1} \mathbf{F}_{2}$ & 25.59 & $2,24,306$ & $2,55,865$ & $1,53,319$ & 1.12 & 126.2 & 0.88 \\
\hline $\mathbf{M}_{1} \mathbf{F}_{3}$ & 28.86 & $2,27,234$ & $2,88,571$ & $3,21,565$ & 1.25 & 245.35 & 0.79 \\
\hline $\mathbf{M}_{2} \mathbf{F}_{1}$ & 31.33 & $2,46,608$ & $3,13,256$ & $3,51,573$ & 1.25 & 266.59 & 0.79 \\
\hline $\mathbf{M}_{2} \mathbf{F}_{2}$ & 33.83 & $2,49,711$ & $3,38,323$ & $4,75,677$ & 1.33 & 354.48 & 0.74 \\
\hline $\mathbf{M}_{2} \mathbf{F}_{3}$ & 38.32 & $2,52,639$ & $3,83,179$ & $7,12,578$ & 1.49 & 522.16 & 0.66 \\
\hline $\mathbf{M}_{3} \mathbf{F}_{1}$ & 20.72 & $2,04,636$ & $2,07,205$ & $-10,481$ & 0.99 & - & 0.99 \\
\hline $\mathbf{M}_{3} \mathbf{F}_{2}$ & 22.13 & $2,07,739$ & $2,21,314$ & 51,705 & 1.04 & 53.56 & 0.94 \\
\hline $\mathbf{M}_{3} \mathbf{F}_{3}$ & 23.97 & $2,10,667$ & $2,39,740$ & $1,39,272$ & 1.11 & 116.24 & 0.88 \\
\hline CD & 1.01 & NS & 2.32 & 69.961 & 0.009 & 0.672 & 0.016 \\
\hline
\end{tabular}

(Note: BC ratio: benefit cost ratio; IRR: internal rate of return)

Main treatments $(\mathrm{M})$ : $\mathrm{M}_{1}$ : Paddy straw mulch; $\mathrm{M}_{2}$ : White plastic mulch; $\mathrm{M}_{3}$ : Control (without mulching)

Sub treatments $(\mathrm{F}): \mathrm{F}_{1}$ : Fertigation with $50 \%$ RDF; $\mathrm{F}_{2}$ : Fertigation with $75 \%$ RDF;

$\mathrm{F}_{3}$ : Fertigation with $100 \%$ RDF

NS: Non-significant; CD: Critical difference $(\mathrm{p}<0.05)$

\section{Internal rate of return}

Internal rate of return (IRR) is the discount rate at which the net present worth (NPW) of a project becomes zero. The higher the IRR value, more desirable the project would be. The highest IRR was obtained under plastic mulch with fertigation of $100 \%$ RDF, i.e. $522 \%$. This was followed by plastic mulch with fertigation of $75 \% \mathrm{RDF}$, i.e. $354 \%$ and plastic mulch with fertigation of $50 \% \mathrm{RDF}$, i.e. $266 \%$. The lowest IRR values were obtained from the control treatments (Table 4).

\section{Payback period}

Payback period indicates the period required in years for returning the profit, hence smaller the values, preferably less than a year, more feasible the project would be. Though the drip system with mulching required higher initial investment, this could be returned within less than a year as evidenced from the present study. This economic analysis was on par with the findings of many other studies on similar line. The lower payback periods of $0.66,0.74$ and 0.79 years were observed under the treatments $\mathrm{M}_{2} \mathrm{~F}_{3}$ (plastic mulch with fertigation of $100 \%$ RDF), $\mathrm{M}_{2} \mathrm{~F}_{2}$ (plastic mulch with fertigation of $75 \%$ RDF) and $\mathrm{M}_{2} \mathrm{~F}_{1}$ (plastic mulch with fertigation of $50 \%$ RDF), respectively. Paddy straw mulch treatments were also economical than the control treatments and similar results for economic feasibility were obtained by Roy and Kaur (2015).The residual control treatments had the highest payback period of 1.22 years, hence adoption of the treatment would be uneconomical (Table 4).

In conclusion the highest net present worth (NPW) was observed under the plastic mulch treatment with fertigation of $100 \% \mathrm{RDF}$ 
$\left(\mathrm{M}_{2} \mathrm{~F}_{3}\right)$, i.e. Rs. 712578. The NPW from plastic mulched treatments were 400 to $800 \%$ higher than the control treatments, whereas the paddy straw mulched treatments resulted in 130 to $196 \%$ increase in NPW compared to control treatments. The highest benefit cost ratio and internal rate of return (IRR) were under plastic mulch with fertigation of $100 \%$ $\operatorname{RDF}\left(\mathrm{M}_{2} \mathrm{~F}_{3}\right)$, i.e. 1.49 and $522 \%$, respectively. The lower payback periods of 0.66 years was observed under the treatments $\mathrm{M}_{2} \mathrm{~F}_{3}$. Control treatment with fertigation of $50 \% \mathrm{RDF}$ and residual control treatment were uneconomical with $\mathrm{BC}$ ratio of 0.99 and 0.80 and payback period of 0.99 and 1.22 , respectively.

From the economic feasibility analysis, it can be concluded that, the drip fertigation with plastic mulch is an economically viable option to be recommended among farmers in arid and semi arid climate. The results pertained to assumption that a single crop season was taken in a year. The limitation of higher initial investment involved can be overcome through subsidized schemes.

\section{Acknowledgement}

The authors are highly grateful for AICRP on Plasticulture Engineering and Technology for the financial assistance in carrying out the experiment during 2018-2020. Also, the first author thanks ICAR for providing SRF fellowship during the doctoral study.

\section{References}

Anisuzzaman, M., Ashrafuzzaman, M., Ismail, R., 2009. Planting time and mulching effect on onion development and seed production. African J. of $\begin{array}{llll}\text { Biotech. } & 8 & \text { (3): } & 412-416 .\end{array}$ https://core.ac.uk/download/pdf/429925 39.pdf.

Chauhan, P., Srivastava, S. K., Denis, D. M., Singh, V., Singh, D. V., 2017. Effect of irrigation scheduling on economic return of onion. Int. J. of Curr. Microbio. and App. Sci. 6 (11): 54545459. 10.20546/IJCMAS.2017.611.522. Filipović, V., Romić, D., Romić, M., Borošić, J., Filipović, L., Mallmann, F. J. K., Robinson, D. A., 2016. Plastic mulch and nitrogen fertigation in growing vegetables modify soil temperature, water and nitrate dynamics: experimental results and a modeling study. Agrl. Water Manag. 176 (1): 100-110.

https://doi.org/10.1016/j.agwat.2016.04. 020.

Jiang, R., Li, X., Zhu, W., Wang, K., Guo, S., Misselbrook, T., Hatano, R.. 2018. Effects of the ridge mulched system on soil water and inorganic nitrogen distribution in the Loess Plateau of China. Agrl. Water Manag. 203 (1): 277-288.

https://doi.org/10.1016/j.agwat.2018.03. 027.

Kader, M. A., Singha, A., Begum, M. A., Jewel, A., Khan, F. H., Khan, N. I., 2019. Mulching as water saving technique in dryland agriculture: review article. Bull. of the National Res. Centre. 43 (1): 147-152. https://link.springer.com/article/10.1186 /s42269-019-0186-7.

Lakew, W. J., Anteneh, B. A., Ayalew, L. T., 2014, Yield and water use efficiency of mulched drip-irrigated onion in low land regions of Amhara, North Central Ethiopia. Univ. J. of Agri. Res. 2 (6): 203-210. 10.13189/ujar.2014.020604.

Lalitha, M., Thilagam, V. K., Balakrishnan, N., Mansour, M., 2010, Effect of plastic mulch on soil properties and crop growth-a review. Agri. Rev. 31 (2): 145-149. https://arccjournals.com/journal/agricult ural-reviews/ARCC1349.

Li, S., Li, Y., Lin, H., Feng, H., Dyck, M., 
2018. Effects of different mulching technologies on evapotranspiration and summer maize growth. Agrl. Water Manag. $201 \quad$ (1): 309-318. https://doi.org/10.1016/j.agwat.2017.10. 025.

Ma, D., Chen, L., Qu, H., Wang, Y., Misselbrook, T., Jiang, R., 2018. Impacts of plastic film mulching on crop yields, soil water, nitrate, and organic carbon in Northwestern China: A meta-analysis. Agrl. Water Manag. $202 \quad$ (1): 166-173. https://doi.org/10.1016/j.agwat.2018.02. 001.

Ortola, M. P., Knox, J. W., 2015. Water relations and irrigation requirements of onion (Allium cepa L.): A review of yield and quality impacts. Expl. Agri. 51 210-231. 10.1017/S0014479714000234.

Patel, C. J., Patel, Z. G., Patel, R. B., 1983. Integrated weed management in onion bulb crop. Indian J. of Weed Sci. 15 (1): 7-11.

Peng, Z., Ting, W., Haixia, W., Min, W., Xiangping, M., Siwei, M., Rui, Z., Zhikuan, J., Qingfang, H., 2015. Effects of straw mulch on soil water and winter wheat production in dryland farming. Scient. Reports. 5 (1): 1-12. https://www.nature.com/articles/srep10 725.

Quintanilla-Tornel, M. A., Wang, K. H., Tavares, J., Hooks, C. R. R., 2016. Effects of mulching on above and below ground pests and beneficials in a green onion agroecosystem. Agrl. Ecosys. and Envir. 224 (1): 75-85. 10.1016/j.agee.2016.03.023

Ram, H., Dadhwal, V., Vashist, K. K., Kaur, H., 2013. Grain yield and water use efficiency of wheat (Triticul aestivum L.) in relation to irrigation levels and rice straw mulching in North West India. Agrl. Water Manag. 128 (1): 92-
101. 10.1016/J.AGWAT.2013.06.011.

Rao, K. V. R., Gangwar, S., Aherwar, P., Yadav, D., 2019. Growth, yield, economics and water use efficiency of onion (Allium cepa L.) under different micro irrigation systems. J. Pharmacog. and Phytochem. 8 (3): 3866-3869. https://www.phytojournal.com/archives/ 2019/vol8issue3/PartBE/8-3-212766.pdf.

Reddy, M., Ayyanagowdar, M. S., Nemichandrappa, M., Balakrishnan, P., Patil, M. G., Polisgowdar, B. S., Satishkumar, U., 2012. Techno economic feasibility of drip irrigation for onion (Allium cepa L.). Karnataka J. of Agrl. Sci. 25 (4): 474-478.

Reddy, S. S., Ram, R. P., 2011, Agriculture finance and management. Oxford and IBH Publishing Co. Rvt. Ltd. p. 91-92.

Roy, P., Kaur, M., 2015. Status and problems of paddy straw management in West Bengal. Int. J. Adv. In Agri. and Envir. Engg. 2 (1): 44-48. 10.15242/IJAAEE.ER1015204.

Singha, P., Mondal, T., Patra, K., Mitra, B., 2018. Straw mulch and restricted irrigation effect on productivity and water use in wheat (Triticum aestivem L.) under various crop establishment techniques in Eatern Sub-Himalayan plains of India. Int. J. Curr. Microbio. App. Sci. 7 (2): 1521-1533. 10.20546/ijcmas.2018.702.183.

Steinmetz, Z., Wollmann, C., Schaefer, M., Buchmann, C., David, J., Tröger, J., Schaumann, G. E., 2016. Plastic mulching in agriculture. Trading shortterm agronomic benefits for long-term soil degradation?. Sci. of The Total Envir. $\quad 550 \quad$ (1): $\quad 690-705$ https://doi.org/10.1016/j.scitotenv.2016. 01.153 .

Tan, S., Wang, Q., Xu, D., Zhang, J., Shan, Y., 2017. Evaluating effects of four controlling methods in bare strips on 
soil temperature, water, and salt accumulation under film-mulched drip irrigation. Field Crops Res. 214 (1): 350-358.

https://doi.org/10.1016/j.fcr.2017.09.00 4.

Ujjainiya, P., Choudhary, M. R., 2019. A review on efficacy of weed management methods in onion. Int. J. of Curr. Microbio. and App. Sci. 8 (2): 895-905. https://doi.org/10.20546/ijcmas.2019.80 2.102.

Zribi, W., Aragüés, R., Medina, E., Faci, J. M., 2015, Efficiency of inorganic and organic mulching materials for soil evaporation control. Soil and Till. Res. 148 (1): 40-45.

https://doi.org/10.1016/j.still.2014.12.00 3.

\section{How to cite this article:}

Anjitha Krishna, P. R., B. Maheshwara Babu, A. T. Dandekar, R. H. Rajkumar, G. Ramesh and Balanagoudar, S. R. 2021. Economic Feasibility Analysis of Onion Cultivation under Mulching and Fertigation in Vertisol in Semi-arid Indian Condition. Int.J.Curr.Microbiol.App.Sci. 10(02): 367-376. doi: https://doi.org/10.20546/ijcmas.2021.1002.043 